\title{
ВКЛЮЧЕННОСТЬ ИНСТИТУТА ОБЕСПЕЧЕНИЯ ЗАЩИТЫ УЧАСТНИКОВ ВООРУЖЕННОГО КОНФЛИКТА В СОВРЕМЕННУЮ МЕЖДУНАРОДНУЮ НОРМАТИВНУЮ СИСТЕМУ
}

Аннотация. Предметом исследования является институт обеспечения защиты участников вооруженного конфликта, как общепризнанного института современного международного права. При обстоятельствах установленного международно-правового запрета войны и недопустимости угрозы силой или ее применения институт обеспечения защиты участников вооруженного конфликта выступает в формате поддержания юридической безопасности физических лии в режиме имеющего место вооруженного конфликта. Коль скоро вооруженный конфликт de facto возник, современное международное право через институт обеспечения защиты участников вооруженного конфликта обеспечивает юридическую защиту по всему субъектному составу задействованных здесь физических лии. Метод и методология исследования составляет собой совокупность различных методов научного познания: логический, сочиальный, системный, сравнительный. Основные выводы проведенного исследования сводятся к следующему:По объективным показателям своего существа институт покровительствуемых лиц, как он себя предметно показывает в рамках международного гуманитарного права, носит целостный по форме и законченный по существу характер. Общзий концептуальный посыл здесь состоит в представлении комплекса субъективных прав (по защите в рамках международного права) в ответ на востребование соблюдения норм международного гуманитарного права. Как и в любой иной отрасли права, факт несоблюдения предписываемых обязанностей вводит в действие юридическую ответственность соответствующих фигурантов. Параметры прав субъектов покровительствуемого состава сводятся к праву на гуманное отношение; на уважение личности, чести и достоинства; на защиту и помощь; на покровительство.

Ключевые слова: Международная нормативная система, современный миропорядок, участники вооруженного конфликта, верховенство права, Декларация тысячелетия, защита прав человека, Устав ООН, вооруженный конфликт, Право на жизнь, покровительствуемые лица.

Abstract: The subject of this research is the institution of ensuring protection of the participants of an armed conflict as a generally recognized institution of modern international law. In the conditions of the established international legal prohibition of war and prevention of threat of force or its application, the institution of ensuring protection of the participants of an armed conflict act as the protector of legal security of private parties during an open armed conflict. As soon as an armed conflict has emerged, the modern international law provides legal protection of all involved private parties through the institution of ensuring protection of the participants of an armed conflict. The author makes the following conclusions: according to the objective indexes of its existence, 
the institution of protected individuals, as it subjectively demonstrates itself within the framework of international humanitarian law, carries a character that is integral in its form and complete in its nature. The general concept here consists in presentation of a complex of subjective rights (on protection by international law) as a response to the demand for obedience to the norms of international humanitarian law. As in any other branch of law, incompliance with set responsibilities activates legal responsibility of the corresponding figures. The parameters of rights of the subjects of the protected group are justified by the right to humane treatment; respect, honor, and dignity; defense and aid; protection.

Keywords: Participant of an armed conflict, Supremacy of law, UN Millennium Declaration, Protection of human rights, UN Charter, Armed conflict, Right to life, Protected individuals, Modern world order, International normative system.

овременный миропорядок как миропорядок на основе верховенства права Rule of Law (Декларация тысячелетия 2000 г., Итоговый документ Всемирного саммита 2005 г.) в режиме объективной констатации обозначает себя по факту общего позитива развития современного международного права. А общий позитив развития международного права - это нормоустанавливающее значение Парижского договора 1928 г. об отказе от войны в качестве орудия национальной политики, Устава ООН 1945 г. с его прямой констатации недопустимости угрозы силой или ее применения (п. 4 ст. 2), Декларация тысячелетия 2000 г. и Итогового документа Всемирного саммита 2005 г. с их предметными установлениями по линии режима верховенства права [1, С. 62-67], [2, с. 24], [3, с. 36], [4, с. $345-$ 405], [5, с. 71-86] в системе современных международных отношений, укрепления Международного Суда как главного судебного органа ООН, обеспечения уважения всех международно признанных прав человека и основных свобод.

Концептуально и в параметрах сугубо практической реализации целей современного миропорядка поступательное развитие международной нормативной системы предметно обозначено в режиме правового пространства Организации Объединенных наций. Формат целей ООН конкретно установлен в ст. 1 Устава ООН, а именно: 1) поддержание международного мира и безопасности; 2) развитие международных отношений между нациями на основе принципа равноправия и самоопределения народов; 3) осуществление международного сотрудничества в поощрении и развитии уважения к правам человека и основным свободам для всех, без различия расы, пола, языка и религии; 4) признание $\mathrm{OOH}$ в качестве центра для согласования действий наций в достижении общих целей.

Возведение востребованности уважения прав человека и основных свобод для всех согласно Уставу ООН в ранг целей мирового сообщества предопределило создание императивного принципа (в формате jas cogens) прав человека. По обстоятельствам своей универсальной применимости принцип уважения прав человека предметно себя обозначает в общих параметрах современного миропорядка, где главными критериями являются поддержание международного мира и безопасности, соответственно, недопустимость угрозы силой или ее применения. В формате de facto возникшего вооруженного конфликта принцип уважения прав человека проявляет себя в одном из своих универсальных качеств 
в режиме принципа защиты участников вооруженного конфликта.

Право на жизнь является основополагающим естественным правом человека, то есть его природным, неотъемлемым и неотчуждаемым правом. Названные свойства и качества этого права считаются общепризнанными. По справедливому мнению Е.А. Лукашевой, в международных документах о правах человека и в национальном законодательстве большинства стран мира право на жизнь и непосредственно связанные с ним права - на физическую неприкосновенность, запрет пыток, насилия и рабства, уважение человеческого достоинства, гарантии справедливого правосудия и некоторые другие - наделяются особым статусом и не подлежат приостановлению или ограничению в условиях чрезвычайного положения или вооруженного конфликта [6, с. 547] .

Сравнительный анализ ст. 2 Европейской конвенции о защите прав человека и основных свобод 1950 г., ст. 4 Американской конвенции о правах человека 1969 г. и ст. 4 Африканской хартии о правах человека и правах народов 1981 г. показывает, что все они исключают возможность приостановления права на жизнь, физическую неприкосновенность, ряда других прав человека и тем самым признают их действие в период вооруженных конфликтов. Вместе с тем важно отметить, что применительно к ситуации вооруженного конфликта необходимо точное определение юридических параметров обеспечения защиты физических лиц субъектного состава в рамках права вооруженных конфликтов. Именно с учетом этой особенности в Гаагских конвенциях 1907 г. и Женевских конвенциях о защите жертв войны 1949 г. уточняется круг покровительствуемых лиц, на жизнь которых запрещено покушаться. К ним относятся раненые, больные, военнопленные, гражданские лица. Соответственно, установлен международно-правовой запрет на убийство противника, сложившего оружие, сдавшегося или не имеющего возможность защищаться.

Защита прав человека от бедствий войны, зародившаяся на заре человечества, развивалась в неразрывной связи с развитием цивилизации, пройдя через периоды внезапного ускорения, застоя, возврата к прошлому [7, с. 25] .

Вооруженные конфликты, несмотря на общий запрет угрозы силой или ее применения (п. 4 ст. 2 Устава ООН), продолжаются. Тем самым устанавливается востребованность обеспечения международно-правовой защиты участников вооруженного конфликта.

Анализ опыта современных военных конфликтов показывает, что воинским формированиям Вооруженных Сил все чаще приходится вести борьбу с иррегулярными отрядами боевиков, использующими тактику террора и партизанской войны. При этом боевые действия, как правило, проходят в урбанизированной местности, и проживающее там гражданское население в той или иной степени оказывается вовлеченным в вооруженную борьбу, что неизбежно приводит к значительным жертвам среди мирных жителей $[8$, c. 31$]$.

Международно-правовая защита в период вооруженных конфликтов представляет собой систему норм и принципов, обеспечивающих необходимое содействие всем покровительствуемым лицам. Лицо, находящееся под защитой - это любой человек, который по Женевским конвенциям о защите жертв войны 1949 г. и Дополнительными протоколами 1977 г. имеет право на особую защиту или на особый статус покровительствуемого лица [9, с. 50]. 
Согласно международному гуманитарному праву к покровительствуемым лицам относятся лица, находящиеся под защитой международного договора в формате гуманитарного права. Попав во власть неприятеля, они пользуются определенными правами. В более широком смысле, покровительствуемые лица - это все те, кто во время военных действий находится под защитой договорного или обычного гуманитарного права. В частности, к ним относятся: раненые, больные и лица потерпевшие кораблекрушение из состава вооруженных сил, военнопленные, гражданское население и другие лица, которые не принимают или прекратили принимать участие в боевых действиях, медицинский и духовный персонал, сотрудники гуманитарных организаций и организаций гражданской обороны, а также посредники.

Нормы международного гуманитарного права по защите покровительствуемых лиц регулируют только международные вооруженные конфликты. Правила, относящиеся к вооруженным конфликтам немеждународного характера, не признают особого статуса лиц, принимающих участие в боевых действиях и не определяют жестких категорий покровительствуемых лиц. Эти правила только отмечают общее различие между лицами, использующими силу, и лицами, не использующими или переставшими ее использовать (раненые, больные, пленные, население, не принимающее участие в боевых действиях).

Действительно, Дополнительный протокол II 1977 г. не содержит термина «покровительствуемого лица». Однако, исходя из смыслового значения данного термина, Дополнительный протокол II 1977 г. выделяет целый ряд категорий лиц, обладающих особым международно-правовым статусом, который отличается друг от друга. К этой категории следует отнести лиц, вышедших из строя вследствие ранения либо болезни или сложивших оружие, гражданское население, детей, задержанных лиц.

Право Женевы призвано обеспечить покровительство всем, кто попал в руки противника вследствие международного вооруженного конфликта. Поэтому покровительство, рассматриваемое здесь, является защитой не от неизбежного в условиях войны насилия как такового, а от произвола, чинимого одной воюющей стороной в отношении лиц, принадлежащих другой воюющей стороне, которые в ходе войны оказались под властью первой.

Покровительство этого рода было впервые предоставлено раненым в действующих армиях в 1864 г. Женевской конвенцией об улучшении участи раненных и больных воинов во время сухопутной войны. С 1949 г. оно распространяется на все категории лиц, перечисленных в четырех Женевских конвенциях о защите жертв войны 1949 г. [10, с. 51].

Защита, предоставляемая гражданским лицам в период международного вооруженного конфликта, в общих параметрах международного гуманитарного права определяет себя в следующих юридических категориях.

Суть защиты, предоставляемой гражданским лицам, оказавшимся во власти противника, закреплена в ст. 27 IV Женевской конвенции о защите жертв войны 1949 г. и проявляется в том, что покровительствуемые лица имеют право при любых обстоятельствах на уважение их личности, чести, семейных прав, религиозных убеждений и обряда, привычек и обычаев. С ними будут всегда обращаться гуманно, и, в частности, они будут охраняться от любых актов насилия или запугивания, от оскорблений 
и любопытства толпы. При этом нормы международного гуманитарного права предусматривают необходимые меры контроля по соблюдению прав гражданскому населения и та же статья устанавливает, что в отношении этих лиц стороны, находящиеся в конфликте, могут принимать такие меры контроля или меры обеспечения безопасности, которые могут оказаться необходимыми вследствие войны.

Более конкретные гарантии закреплены в запрещающих нормах: коллективные наказания, меры террора, ограбления, репрессии, взятие заложников.

Во время Второй мировой войны нередки были случаи, когда гражданские лица становились жертвами репрессий. Такие факты зафиксированы, например, в ноте СССР германскому правительству от 27 апреля 1942 г.: «...в деревнях Лотошинского района Московской области гитлеровцы замучили и повесили 153 человека, расстреляли 507 человек, в том числе много женщин и детей, 13 семей заживо сожгли... Только за январь 1942 г. из Харькова поступили сведения о казни 370 заложников в качестве репрессий за действия партизан».

Акты насилия или угрозы насилием, имеющие основной целью терроризировать гражданское население, запрещены международным гуманитарным правом.

Если говорить о защите гражданского населения, то в тех случаях, когда в силу тех или иных причин конкретные ситуации не регламентируются действующими договорными нормами международного права, воюющие стороны обязаны принять все необходимые меры для обеспечения защиты гражданского населения, недопущения ведения боевых действий непосредственно против гражданского населения и отдельных гражданских лиц, предотвращения убийств или ранения гражданских лиц, уничтожения или разрушения гражданских объектов.

В п.3 ст.51 Дополнительного протокола I 1977 г. четко и недвусмысленно указывается, что единственным основанием для прекращения международно-правовой защиты гражданских лиц является непосредственное участие таких лиц в вооруженных действиях. При этом право на предоставление международно-правовой защиты утрачивает не все гражданское население, а лишь те конкретные гражданские лица, которые принимают участие в боевых действиях, и только на тот период, пока продолжается их участие в таких действиях. Это основополагающее положение, впервые сформулированное в качестве договорной нормы международного права, имеет принципиально-важное значение для определения важнейшего условия предоставления защиты гражданским лицам, суть которого заключается в отказе от участия в военных действиях. В этой связи, справедливо отмечают на этот счет ученые, что никакие меры военного воздействия под предлогом военной необходимости или любым другим, не могут быть применены против гражданского населения до тех пор, пока оно не принимает участие в военных действиях на законных основаниях [11, с. 319-329].

В отличие от непосредственного участия гражданских лиц в военных действиях, совершение ими «действий, враждебных по отношению к противнику» (Asts hostile to the enemy), как это вытекает из указанных положений, не может рассматриваться как основание для прекращения защиты гражданских лиц, принимающих участие в такого рода деятельности (которых в международно-правовой литератуpe иногда именуют квазикомбатантами). Поскольку такие действия гражданских лиц, как работа на военных предприятиях, 
участие в строительстве военных объектов и другие аналогичные действия, не являются участием в боевых действиях по смыслу п. 3 ст. 51 Дополнительного протокола I 1977 г., а могут рассматриваться лишь как «действия, враждебные по отношению к противнику», то те гражданские лица, которые принимают участие в подобного рода деятельности, не могут утрачивать право на предоставление международно-правовой защиты в соответствии с Дополнительным протоколом I 1977 г. и другими соглашениями. Вместе с тем следует учитывать, что военные предприятия, на которых работают такие гражданские лица, и другие соответствующие объекты рассматриваются в качестве военных объектов и в силу этого могут быть законными объектами нападений при условии соблюдения других соответствующих требований международного права.

Приоритетный характер принципа защиты гражданского населения перед соображениями военной необходимости убедительно подтверждается формулировками ряда закрепленных в Дополнительном протоколе I 1977 г. и Конвенции о запрещении или ограничении применения конкретных видов обычного оружия 1980 г. норм, запрещающих нападение даже на военные объекты и некоторые объекты смешанного характера, если они могут нанести ущерб гражданскому населению, находящемуся в непосредственной близости от таких объектов. Важность этих положений заключается в том, что они устанавливают определенные ограничения возможности воюющих сторон осуществлять нападения на вооруженные силы и военные объекты противника. Ограничения, сформулированные в этих нормах, направлены на укрепление режима защиты гражданского населения посредством ограничения воюющих в выборе и применении средств и методов ведения войны [11, с. 319-329], $[12$, c. 44]. Однако, речь идет о населении, которое не работает на военных объектах.

В соответствии с IV Женевской конвенцией о защите жертв войны 1949 г. оккупирующая страна обязана при помощи всех имеющихся средств обеспечить снабжение гражданского населения продовольствием и санитарными материалами; обеспечить и поддерживать при содействии национальных и местных властей деятельность санитарных и больничных учреждений и служб, здравоохранение и общественную гигиену на оккупированной территории, в частности, принимая и применяя профилактические и превентивные меры, необходимые для борьбы с распространением заразных болезней и эпидемий.

Согласно ст. 51 Дополнительного протокола I 1977 г. в целях осуществления защиты гражданского населения и отдельных гражданских лиц от опасностей, возникающих в связи с военными операциями, они не должны являться объектом нападения. При любых обстоятельствах запрещаются:

- акты насилия или угрозы насилия, имеющие основной целью терроризировать гражданское население;

- нападение избирательного характера;

- нападение на гражданское население или отдельных гражданских лиц в порядке репрессалий;

- использование присутствия или передвижения гражданского населения или отдельных гражданских лиц для защиты определенных пунктов или районов от военных действий, в частности в попытке защитить военные объекты от нападения или прикрыть военные действия, содействовать или препятствовать им. Стороны, находящиеся в конфликте, не должны направлять передвижения гражданского населения или отдельных гражданских 
лиц с целью попытаться защитить военные объекты от нападения или прикрыть военные операции.

Любое нарушение этих запрещений не освобождает стороны, находящиеся в конфликте, от их правовых обязательств по отношению к гражданскому населению и гражданским лицам, в том числе от обязательства принимать меры предосторожности, предусмотренные в ст.57.

Позиционно, юридическая сущность мер предосторожности при конкретных мерах нападения, проявляет себя в следующих параметрах:

- делать все практически возможное, чтобы удостовериться в том, что объекты нападения не являются ни гражданскими лицами, ни гражданскими объектами и не подлежат особой защите;

- принимать все практически возможные меры предосторожности при выборе средств и методов нападения с тем, чтобы избежать случайных потерь жизни среди гражданского населения, ранения гражданских лиц и случайного ущерба гражданским объектам и конкретных мерах свести их к минимуму;

- воздерживаться от принятия решений об осуществлении любого нападения, которое вызовет случайные потери жизни среди гражданского населения, ранения гражданских лиц и нанесет ущерб гражданским объектам, чрезмерные по отношению к конкретному и прямому военному преимуществу, которое предполагается получить;

- делается эффективное заблаговременное предупреждение о нападениях, которые могут затронуть гражданское население, за исключением тех случаев, когда обстоятельства этого не позволяют.

Когда возможен выбор между несколькими военными объектами для получения равноценного военного преимущества, то избирается тот объект, нападение на который, как можно ожидать, создаст наименьшую опасность для жизни гражданских лиц и для гражданских объектов.

При проведении военных операций на море или в воздухе стороны, находящиеся в вооруженном конфликте, предпринимают все разумные меры предосторожности с тем, чтобы избежать потерь жизни среди гражданского населения и ущерба гражданским объектам.

Концептуально, качественный позитив права несет в себе положение ст. 54 Дополнительного протокола I 1977 г., согласно которому запрещено использовать голод среди гражданского населения в качестве метода ведения войны.

Стороны, находящиеся в конфликте, принимают необходимые меры предосторожности для защиты гражданского населения, отдельных гражданских лиц и гражданских объектов от опасностей, возникающих в результате военных операций. Стороны в максимальной практически возможной степени должны стремиться без ущерба для соблюдения предписаний ст. 49 IV Женевской конвенции 1949 г. удалить гражданское население, отдельных гражданских лиц и гражданские объекты, находящиеся под их контролем, из районов, расположенных вблизи от военных объектов. Кроме того, ст.58 Дополнительного протокола I 1977 г. обязывает избегать размещения военных объектов в густонаселенных районах или вблизи от них [13, ст. 58].

В случае нарушения обязанности не участвовать в вооруженных конфликтах у гражданского населения происходит процесс прекращения международно-правовой защиты. Таким образом, международное гуманитарное право осуществляет международно-правовую защиту гражданского населения в период вооруженных конфликтов при условии неучастия гражданского 
населения в вооруженных конфликтах. В этом смысле юридический факт участия гражданского населения в вооруженных конфликтах прекращает действие устанавливаемой международным гуманитарным правом международно-правовой защиты.

Согласно IV Женевской конвенции о защите жертв войны 1949 г. система норм, применяемая к иностранцам на территории государств, которые находятся в состоянии войны, строится так, чтобы сохранить насколько это возможно, права, которыми они пользуются в мирное время.

Статья 35 IV Женевской конвенции о защите жертв войны 1949 г. закрепляет положение о том, что за иностранцем сохраняется право покинуть территорию, если его выезд не противоречит интересам страны.

В отношении иностранцев, которые добровольно или по принуждению, не покидают территорию, предусмотрены гарантии как на тот случай, если они свободно проживают в стране, так и на случай лишения свободы по приговору суда или по соображениям безопасности (принудительное поселение в определенном месте или интернирование).

Согласно ст. 41 IV Женевской конвенции о защите жертв войны 1949 г. самой суровой мерой контроля, к которой могут прибегнуть власти, является интернирование или принудительное поселение в определенном месте. «Распоряжение об интернировании или принудительном поселении... может быть дано лишь в том случае, если это совершенно необходимо для безопасности державы, во власти которой эти лица находятся» [14, ст. 30, 42, 43]. Однако эта мера должна быть отменена, как только исчезнет настоятельная необходимость, вызванная соображениями безопасности. На основании ст. 43 IV Женевской конвенции о защите жертв войны 1949 г., вопрос об интернировании каждого лица должен пересматриваться, по крайней мере, два раза в год. ДержавеПокровительнице и Международному Комитету Красного Креста должны высылаться официальные извещения о принятии таких мер, а их делегатам должен предоставляться свободный доступ к лицам, в отношении которых эта мера применена [14, ст. 30, 42, 43]. Постановочно, IV Женевская конвенция о защите жертв войны 1949 г. (статьи с 79 по 135) посвящена исключительно обращению с интернированными. Содержащиеся в ней нормы по своему содержанию в юридическом плане сопоставимы с нормами определяющими статус военнопленных, которые, также как и интернированные гражданские лица, не являются правонарушителями. В постановочном плане ст. 78 IV Женевской конвенции применяет к покровительствуемым лицам, те же ограничительные меры и те же гарантии, касающиеся обращения на оккупированной территории.

Международно-правовой режим защиты детей в период международных вооруженных конфликтов при всех обстоятельствах своей специфики (по факту субъектного состава лиц, находящихся под защитой) вписывается в общие юридические стандарты обеспечения защиты гражданского населения.

Соответственно, согласно ст. 77 Дополнительного протокола I, устанавливающей особый режим защиты для детей, воюющие стороны обязаны предпринимать все возможные меры для того, чтобы дети, не достигшие 15-летнего возраста, не принимали непосредственного участия в военных действиях. Тем не менее, они продолжают пользоваться особой защитой, предусмотренной ст.77, даже если участвуют в военных действиях и попадают во власть противной стороны [15, с. 248]. 
Международный Комитет Красного Креста (МККК) в порядке реализации своей общей заинтересованности по обеспечению выполняемости норм и принципов международного гуманитарного права применяет в последовательном порядке надлежащие меры по поддержанию целостности международно-правового режима защиты детей в период вооруженных конфликтов. В январе 1939 г. МККК и Международный союз Фонда спасения детей разработали проект конвенции о защите детей в период вооруженных конфликтов. К сожалению, начало Второй мировой войны помешало принятию этой конвенции. Сразу после окончания войны МККК возобновил свои усилия по созданию особых положений, направленных на защиту детей.

В 1949 г. была принята IV Женевская конвенция о защите гражданского населения во время войны. В ней содержится более 17 статей, касающихся обеспечения на всесторонней основе защиты детей в период вооруженных конфликтов.

В конфликтах, имевших место со времени принятия Конвенции, жертвами являлись большей частью гражданские лица, и прежде всего женщины и дети. Тот факт, что было убито так много гражданских лиц, включая детей, объясняется в значительной мере применением новых, неизбирательных методов и средств ведения войны [16, с. 108]. Кроме того, в наиболее распространенном типе конфликтов последнего времени - столкновении регулярных войск с партизанскими силами - широкое распространение получило участие несовершеннолетних в боевых действиях. Что касается вопроса участия детей в военных действиях, то в целях ограничения участия детей в вооруженных конфликтах в принятых в 1977 г. Дополнительных протоколах I и II содержится положение, устанавливающее эти ограничения, а также защита прав детей.
Постановочное значение в плане своей международно-правовой предметной сущности имеют положения ст. 77 Дополнительного протокола I 1977 г., согласно которым дети пользуются особым уважением, и им обеспечивается защита от любого рода непристойных посягательств. Стороны, находящиеся в конфликте, обеспечивают им защиту и помощь, которые им требуются ввиду их возраста или по любой другой причине.

В случае ареста, задержания или интернирования дети содержатся в помещениях, отдельных от помещений для взрослых. В отношении лиц, не достигших 18 -летнего возраста на момент совершения правонарушения, связанного с вооруженным конфликтом, не приводится в исполнение смертный приговор [13, ст. 58].

Статья 23 IV Женевской конвенции 1949 г. гарантирует детям до 15-летнего возраста, беременным женщинам и роженицам право получать все посылки с медицинскими и санитарными материалами, необходимыми продуктами питания, носильными вещами и укрепляющими средствами.

Специальные положения, касающиеся детей, которые осиротели или были разлучены со своими семьями, предусмотрены ст. ст. 24 и 50 IV Женевской конвенцией 1949 г.

Наконец, ст. 132 IV Конвенции 1949 г. призывает освободить, репатриировать и возвращать на место постоянного проживания или размещать в нейтральной стране детей, беременных женщин и матерей с малолетними детьми.

Ребенок может быть интернирован подобно другому покровительствуемому лицу. Ему также может быть предъявлено обвинение, как это бывает в мирное время в нарушении уголовного законодательства на оккупированной территории или в совершении актов, наносящих ущерб 
безопасности оккупирующей державы. Фактически, вопреки международному гуманитарному праву он может быть зачислен в вооруженные силы и захвачен в плен как лицо, принимающее участие в боевых действиях в составе вооруженных сил. Учитывая подобные ситуации, международное гуманитарное право предусматривает специальное положение, касающееся детей, которые таким образом лишены свободы.

Позиционно, IV Женевская конвенция 1949 г. предусматривает размещение детей вместе с их интернированными родителями, а Дополнительный протокол I 1977 г. распространяет положение о таком размещении на всех, кто находится во власти стороны в конфликте.

В отношении тех случаев, когда дети берутся за оружие, правовые положения Дополнительных протоколов 1977 г. реалистичны: Протокол I, статья 77, пункт 3, предусматривает, что если упомянутая выше статья 77, пункт 2, нарушена и дети до 15 лет принимают участие в конфликте и попадают в руки противника, они, тем не менее, продолжают пользоваться защитой, предоставляемой ст. 77, независимо от того, являются они военнопленными или нет. Протокол II, статья 4, пункт 3d, содержит аналогичное положение, которое применяется к конфликтам немеждународного характера [17, с. 44].

Существующие международно-правовые акты, регулирующие положение ребенка во время вооруженного конфликта, отражают комплексность проблемы. Это Всеобщая декларация прав человека 1948 г., Женевские конвенции 1949 г. о защите жертв войны, в особенности IV Женевская конвенция 1949 г., Дополнительные протоколы к ним 1977 г., международные соглашения о запрещении определенных видов оружия, Конвенция о правовом статусе беженцев 1951 г. и Протокол к ней 1967 г., Конвенция МOT № 182 о запрещении и немедленных мерах по искоренению наихудших форм детского труда 1999 г., а также Конвенция о правах ребенка 1989 г., Римский статут Международного уголовного суда 1998 г., Конвенция против пыток и других жестоких бесчеловечных или унижающих достоинство видов обращения и наказания 1984 г. и многие другие. В рамках международных региональных организаций, а также специализированных учреждений $\mathrm{OOH}$ также заключены различные соглашения, регулирующие и в полной мере обеспечивающие правовой статус ребенка в вооруженном конфликте.

Предметная заинтересованность мирового сообщества в деле по обеспечению защиты детей в период вооруженных конфликтов в полной мере проявляет себя в параметрах Конвенции о правах ребенка 1989 г., которая обладает рядом уникальных характеристик касающихся положения детей в условиях вооруженного конфликта. В ней в полном объеме сформулированы политические, гражданские, экономические, социальные и культурные права детей; в нее инкорпорированы нормы гуманитарного права; она полностью остается в силе в ситуации вооруженного конфликта. Конвенция обязывает участвующие в конфликте государства содействовать физической и психосоциальной реабилитации и социальной реинтеграции детей, являющихся жертвами вооруженных конфликтов, она обязывает государства применять ее положения ко всем детям, находящимся под их юрисдикцией, без какой-либо дискриминации. Например, дети, спасающиеся от войны в своих родных странах и ищущие убежища в другом государстве-участнике, должны пользоваться защитой в полном объеме. Конвенция требует от государств-участ- 
ников принять эффективные меры для ликвидации социальной практики, пагубно сказывающиеся на здоровье детей. Сюда, несомненно, относится и практика, подвергающая детей опасностям в условиях вооруженного конфликта. В Женевских конвенциях 1949 г. о защите жертв войны и Дополнительных протоколах к ним 1977 г. содержатся многочисленные положения, касающиеся конкретно детей. Принятый в 1998 г. Римский статут Международного уголовного суда квалифицирует как военное преступление следующие виды преступных деяний: 1) набор или вербовку детей в возрасте до 15 лет в состав национальных вооруженных сил и их использование для участия в боевых действиях; 2) умышленные нападения на гражданское население или на персонал и транспортные средства, задействованные в оказании гуманитарной помощи и нанесение ударов по госпиталям и учебным зданиям. Статут квалифицирует насильственную передачу детей из находящейся под угрозой национальной, этнической, расовой или религиозной группы в другую группу как геноцид, а изнасилование и обращение в сексуальное рабство квалифицируются как военные преступления и как преступления против человечности. Конвенция МОТ 1999 г. (№ 182) о ликвидации наихудших форм детского труда запрещает насильственный или принудительный набор детей в возрасте до 18 лет для использования в вооруженных конфликтах. Африканская хартия прав и благосостояния ребенка, вступившая в силу в 1999 г., запрещает вербовку любого лица в возрасте до 18 лет или его прямое участие в боевых действиях или внутренних распрях.

Показательное международно-правовое значение в плане упорядочения института прав детей имеет резолюция 51/77 от 12 декабря 1996 г., которая по факту своего при- нятия учредила должность Специального представителя Генерального Секретаря по вопросам детей в вооруженных конфликтах. Такое решение Генеральной Ассамблеи об учреждении специальной должности в данной сфере было инициировано докладом специального докладчика ООН Грасы Машел 26 августа 1996 г. о последствиях вооруженных конфликтов для детей [18, с. 217].

Таким образом, должность Специального представителя Генерального Секретаря по вопросам детей в вооруженных конфликтах была учреждена с целью улучшения согласованности действий различных органов и организаций $\mathrm{OOH}$ по защите детей, а также для усиления направления информационной деятельности ООН и работ по сбору фактов о текущей ситуации в мире.

В режиме объективной констатации, дети, непосредственно участвующие в конфликте, это не только дети с оружием в руках. Одним из обычных занятий таких детей является служба в качестве носильщика, в том числе и очень тяжелых грузов, включая оружие, боеприпасы, транспортировку раненных. Соответственно дети подвергаются жестокому избиению, иногда расстрелу, используются также для ведения хозяйства, добычи пропитания для солдат. В Уганде, согласно данным, опубликованным в докладе Грасы Машел, дети-солдаты часто выполняли функции охраны постов, работали в огородах и садах. Во многих странах детей используют в качестве посыльных и разведчиков, что приводит к тому, что все дети становятся подозреваемыми и часто бывают уничтожены «по подозрению в пособничестве врагу».

При представлении проекта Протокола I официальный представитель МККК (Н. Сурбек) справедливо констатировал следующее: «Слишком часто дети использовались стороной в конфликте в качестве 
непосредственных участников боевых действий или помогали выполнять другие поручения военного характера. Детям, конечно, очень нравилось чувствовать себя нужным, и, считая себя взрослым, они бывали совершенно счастливы. Воспользоваться этим чувством было особенно отвратительным, поскольку дети, совершающие такие действия, подвергались такому же риску, как и взрослые комбатанты, но, в отличие от взрослых, они не всегда четко понимали, что их ожидало за прямое или косвенное участие в военных действиях» [19, с. 135].

Международное гуманитарное право содержит стройную систему институтов и норм, касающихся защиты женщин и детей в вооруженных конфликтах. В последнее время специальный международно-правовой режим защиты детей значительно укрепился за счет принятия Факультативного протокола к Конвенции о правах ребенка, касающегося участия детей в вооруженных конфликтах, и, отчасти, Римского статута Международного уголовного суда. Вместе с тем актуальной остается задача закрепления в международном договоре 18 -летнего возрастного лимита для добровольного набора в вооруженные силы государств. Не менее важно предпринять комплекс мер, направленных на эффективное осуществление вышеуказанных правовых норм и обеспечить политико-правовыми способами соблюдение государствами своих обязательств в данной области [20, с. 74-76], [21, с. 217].

Таким образом, у детей, во время международного вооруженного конфликта по факту кодификационной деятельности мирового сообщества был выработан целостный комплекс субъективных прав и обязанностей, который обеспечивает всесторонний правовой формат защиты с точки зрения права и справедливости.
В ситуации международного вооруженного конфликта женщины, как часть гражданского населения, находятся под защитой норм международного гуманитарного права, устанавливающих ограничения на ведение военных действий. Статья 14 III Женевской конвенции 1949 г. указывает, что с женщинами следует обращаться во всех случаях, не хуже, чем с мужчинами.

Принцип равного обращения дополняется еще одним принципом, гласящим, что «к женщинам будут относиться со всем полагающимся их полу особым уважением» (I и II Женевская конвенция 1949 г., ст. 12; III Женевская конвенция 1949 г., ст. 14). Институционно-правовой статус «особое уважение» предоставляемый женщинам, включает в себя комплекс определенных понятий, а именно физиологические особенности, честь и нравственность, беременность и роды.

В условиях международного вооруженного конфликта категория женщин (беременные или роженицы) пользуется особой защитой.

Наряду с ранеными, больными и инвалидами роженицы принадлежат к той категории лиц, транспортировка которых по суше, воде и воздуху должна пользоваться уважением и покровительством.

Предметно качественный позитив права несут в себе положения п. 2 ст. 76 Дополнительного протокола I, в соответствии с которым дела беременных женщин и матерей малолетних детей, подвергаемых аресту, задержанию или интернированию по причинам, связанным с вооруженным конфликтом, рассматриваются в первоочередном порядке. Из данной статьи вытекает, что в первую очередь рассматривается вопрос скорейшего освобождения беременных женщин.

Международно-правовую значимость несут в себе положения ст. 89 IV Женевской 
конвенции 1949 г., которая содержит положение предусматривающее, что беременные, роженицы и дети до 15 лет должны получать дополнительное питание в соответствии с их физиологическими потребностями. Этот пункт был введен для того, чтобы избежать болезней связанных с недостаточностью питания, которые были бы особенно нежелательны у таких женщин, поскольку это скажется на здоровье будущих поколений [20, с. 74-76], [21, с. 217].

Обеспечение охраны здоровья в условиях вооруженных конфликтов является первоочередной задачей при обстоятельствах, когда это приводит к ухудшению условий жизни, нарушает социальный и экологический баланс, что губительно сказывается на здоровье людей. Вооруженный конфликт может ввергнуть все население в нищету и стать причиной болезней, при этом для наиболее уязвимых групп населения смертельный исход часто является неизбежным.

Таким образом, женщины имеют право на гуманное обращение, пользоваться уважением и покровительством, получать дополнительное питание и посылку с медикаментами (в особенности беременные женщины и роженицы), на охрану здоровья. При этом они должны воздерживаться от любых враждебных действий.

Международное гуманитарное право обеспечивает уважение и покровительство медицинскому персоналу, работающему в зоне вооруженного конфликта.

Пр авовой анали положе ни й Дополнительного протокола I 1949 г. позволяет сделать вывод о том, что медицинский персонал включает в себя лиц, назначенных стороной, находящейся в конфликте, исключительно для медицинских целей, для административно-хозяйственного обеспечения медицинских формирований, для работы на транспортно-санитарных средствах и для их санитарно-технического обеспечения.

Медицинский персонал может быть гражданским и военным, т.е. медицинские работники, находящиеся на военной службе по призыву или контракту. Гражданский и военный медицинский персонал должен быть назначен стороной, находящейся в конфликте. Это предполагает издание соответствующих нормативных правовых актов (приказов, распоряжений и т.д.) военным командованием о назначении конкретных лиц в медицинские формирования. Такие акты, в каждом конкретном случае, будут являться подтверждением принадлежности конкретного лица (гражданского или военного) к медицинскому формированию (лазарету, санитарной группе и т.д.) и служить, в определенной мере, «охранной грамотой» перед противником в случае выяснения принадлежности захваченных в период боевых действий лиц, отличия их от членов преступных групп, занимающихся разбоем, мародерством и т.д. Именно на основе приказа военного командования весь медицинский персонал получает персональные удостоверения личности, определяющие их особый статус [22, c. 200].

В ст. 26 І Женевской конвенции 1949 г. содержится положение о том, что личный состав национальных обществ Красного Креста и других добровольных обществ помощи, надлежащим образом признанных и уполномоченных своим правительством, приравнивается к военному медицинскому персоналу.

Медицинский персонал должен воздерживаться от проявления любых враждебных действий по отношению к другой воюющей стороне, в том числе, к раненым и гражданскому населению.

Медицинский персонал находится под защитой норм международного права и 
обязан соблюдать нейтралитет в вооруженном конфликте, в ходе которого он занимается оказанием медицинской помощи. Нейтралитет в данном случае означает всяческий отказ и недопущение любого вмешательства в вооруженный конфликт, т.е. участия в боевых действиях. Это является главным образом условием, на основании которого медицинскому персоналу предоставляется особая защита. В случае, если медицинский персонал перестает быть нейтральным и использует свой статус для оказания помощи одной из сторон конфликта (сбор и передача данных о передвижении противника, обеспечение оружием, продуктами питания его разведывательных групп, транспортировку под видом раненных вооруженных групп и т.д.), он теряет право на защиту и другая воюющая сторона вправе рассматривать такой медицинский персонал как комбатантов.

Медицинский персонал должен располагать опознавательными знаками и документами. Например, на белом фоне большой красный крест (или другие эмблемы) на груди и спине сотрудника медицинского персонала, а также на транспортных средствах. Кроме того, сотрудники медицинского персонала должны иметь удостоверение личности. Сторонам, находящимся в конфликте, строго предписано осуществлять постоянный контроль за использованием отличительной эмблемы, удостоверений личности, пресекать и предотвращать злоупотреблениями ими. Медицинский персонал предоставляет помощь всем нуждающимся в равной мере, без каких-либо различий, т.е. больным и раненым, как своего государства, так и другой воюющей стороны.

На медицинском персонале, работающем в зоне вооруженного конфликта, лежит большая ответственность. Он должен сознавать, что нарушение международного гуманитарного права может не только вызвать тяжелейшие последствия для жертвы или жертв этого нарушения и, в случае обнаружения, для самого медицинского персонала, но и поставить под угрозу всю систему защиты, установленную международным гуманитарным правом и основанную на доверии.

Международное гуманитарное право обеспечивает уважение и покровительство медицинскому персоналу, работающему в зоне вооруженного конфликта. Это означает, что его следует щадить, не подвергать нападению, защищать, оказывать помощь и поддержку. Право на уважение и покровительство действительно при любых обстоятельствах, а вытекающие из него обязанности возлагаются на всех, но, разумеется, прежде всего на военнослужащих, независимо от того, к какой стороне они принадлежат.

Члены медицинского персонала ни в коем случае не могут отказаться ни от каких прав, которые им обеспечивает международное гуманитарное право. Как отмечалось выше, цель этого положения, которое одинаково распространяется на всех покровительствуемых лиц, состоит в обеспечении их полной защиты. Эта категорическая запретительная норма была установлена для того, чтобы предотвратить возможное давление на медицинский персонал с целью принудить его отказаться от своих прав, а также, чтобы не допустить попыток оправдать правонарушения якобы полученным согласием жертв [23, с. 29].

Следовательно, для того чтобы находиться под покровительством Конвенции любые средства санитарных перевозок должны быть предназначены исключительно для медицинских целей.

Санитарно-транспортные средства пользуются уважением и защитой. Проявлять к ним уважение - значит не 
нападать на них, не повреждать, не мешать их передвижению, т.е. позволять им выполнять поставленную перед ними задачу. Защита означает активное обеспечение покровительства, что в соответствующих обстоятельствах предполагает защиту санитарно-транспортных средств от третьей стороны или иную подобную поддержку [23, с. 29].

Важная привилегия предоставляется медицинскому или духовному персоналу, попавшему в руки противника: эти лица не должны рассматриваться как военнопленные. Держащая в плену держава может, однако, задерживать их, если они необходимы для ухода за военнопленными, числящимися за той стороной в конфликте, к которой они сами принадлежат.

Четвертая Женевская Конвенция 1949 г. о защите жертв войны, специально предназначенная для защиты гражданских лиц, имеет положение, в соответствии с которым «лица, занимающиеся систематически и исключительно обслуживанием и управлением гражданских больниц, включая персонал, предназначенный для розыска, сбора, транспортировки и лечения, раненых и больных гражданских лиц, инвалидов и рожениц», пользуются уважением и покровительством».

Правовое положение медицинского персонала в период международных вооруженных конфликтов в параметрах комплекса прав и соответствующих этим правам обязанностей носит целостный по форме и законченный по содержанию характер.

В формате современного международного права понятие «духовный персонал» было предметно расширено и стало охватывать как военных, так и гражданских лиц (в качестве примера приведены священники); они также могут быть приданы вооруженным силам на временной или постоянной основе [24, с. 29].
Следует отметить, что положения п. d ст. 8 Дополнительного протокола I 1977 г. дают качественно новое определение «духовный персонал», к которому ранее (в соответствии с Женевскими конвенциями 1949 г.) относились только «священнослужители». Теперь же, они упоминаются лишь как часть духовного персонала, что позволяет толковать данное положение в пользу включения в данную категорию покровительствуемых лиц персонала, как вооруженных сил, так и приданных им на постоянной или временной основе специалистов, занимающися оказанием психологической помощи, духовной поддержки участникам и жертвам конфликта, даже если такая поддержка не имеет религиозного или культового характера. Наконец, п. 5 ст. 15 Дополнительного протокола I 1977 г. четко указывает, что положения всех четырех Женевских конвенций о защите жертв войны 1949 г. и настоящего Протокола, касающиеся защиты и опознавания медицинского персонала, в равной степени применимы и к гражданскому духовному персоналу, что позволяет говорить об идентичности специального международно-правового режима защиты этих двух категорий покровительствуемых лиц [11, с. 319-329], [20, с. 74-76].

Весь позитив международного гуманитарного права, как он себя показывает применительно к конкретным субъектам правоотношений в период международных вооруженных конфликтов, применим и к субъектному составу журналистского корпуса.

Журналист, находящийся в опасной командировке в зоне боевых действий, является гражданским лицом, он пользуется всеми правами, предоставляемыми гражданским лицам как таковым. Позиционно, с точки зрения современного международного права (Женевские конвенции 
1949 г. о защите жертв войны) журналист, занимающийся своей профессиональной деятельностью во время конфликта всегда будет пользоваться надлежащей международно-правовой защитой.

При условии, когда журналист не совершает никаких действий, которые могли бы поставить под сомнение его статус гражданского лица, журналист пользуется защитой в соответствии с Женевскими конвенциями о защите жертв войны 1949 г. и Протоколами I и II 1977 г. на тех же основаниях, что и все прочие гражданские лица. Таким образом, можно сделать вывод, о том, что применительно к статусу журналистов речь идет о защите гражданского населения вообще. Однако тем самым следует констатировать, что защита предоставляется гражданским лицам независимо от их гражданства.

Постановочно значимо с точки зрения современного международного права то положение, согласно которому военный корреспондент, аккредитованный военными властями по смыслу III Женевской конвенцией 1949 г., пользуется той же защитой, что и не аккредитованный журналист: за ним сохраняется статус гражданского лица, несмотря на особые права, полученные от военных властей. Точно также к журналисту нужно проявлять уважение вне зависимости от того, есть ли у него удостоверение личности журналиста, находящегося в опасной командировке. Такое удостоверение подтверждает, что его владелец является журналистом, но оно не предоставляет своему владельцу статуса гражданского лица.

Постановочно, журналист может утратить не право на защиту, которое он имеет в соответствии со своим статусом гражданского лица, а фактически предоставляемую ему защиту, если он следует за военным формированием, находясь от него на слишком близком расстоянии. Он не сумеет пользоваться защитой, на которую имеет право, если такое формирование станет законным объектом нападения со стороны противника (если только нападение не является нарушением принципа соразмерности - п. 5 b, ст. 51). При таких обстоятельствах он действует на свой страх и риск.

Кроме того, любое непосредственное участие в военных действиях переводит его в категорию комбатантов и на него распространяется режим военного плена.

Таким образом, журналисты защищены в той же степени, что и основная масса людей, не принимающих участие в военных действиях, - гражданское население.

Деятельность журналиста в ходе конфликта, как международного, так и внутреннего, всегда будет связана с риском, причем, надо сказать, журналисты нередко сами сознательно подвергают себя опасности. Нормы права не всегда могут защитить их от последствий добровольно принятого решения, от риска, на который они идут по собственной воле [15, с. 248].

Вместе с тем любое лицо, входящее в состав вооруженных сил и выполняющее функции по сбору и опубликованию информации, не является журналистом по смыслу ст. 79 Дополнительного протокола I и не пользуется статусом гражданского лица.

Следует отметить, что проект международной конвенции по защите журналистов, который разрабатывался в 1970-75 гг. в рамках Комиссии ООН по правам человека, предусматривал создание принципиально нового специального режима защиты журналистов без какой-либо его привязки к статусу гражданского лица. Однако впоследствии было принято решение отказаться от разработки отдельной конвенции по защите журналистов и включить ее ба- 
зовые формулировки в Дополнительный протокол I 1977 г.

Последующая правоприменительная практика доказала правильность такого подхода, т.к. все положения Женевских конвенций и Дополнительных протоколов к ним, касающиеся защиты гражданского населения, применяются и к журналистам. Причем, обе категории журналистов (аккредитованные при вооруженных силах по смыслу ст. 4 А (4) III Женевской конвенции и «независимые») пользуются защитой в соответствии со всем комплексом международно-правовых норм. Так, например, в случае пленения первая из вышеуказанных категорий журналистов будет пользоваться защитой в качестве военнопленных, а вторая - в качестве гражданских лиц в соответствии c IV Женевской конвенцией и Дополнительным протоколом I 1977 г.

Вместе с тем журналист лишается защиты, если он предпринимает действия, «отрицательно воздействующие на его статус как гражданского лица» (\$2 ст. 79). Следовательно, журналист de jure теряет международно-правовую защиту в случае прямого участия в военных действиях в любой форме. Как показывает практика, сотрудники средства массовой информации (СМИ) также могут терять международно-правовую защиту de facto в случае несоблюдения правил разумной предосторожности в условиях вооруженного конфликта или установления излишне тесных связей с одной из сторон конфликта. Такие действия журналистов создают дополнительные трудности в их идентификации и обеспечении соответствующей защитой. Причем предусмотренное $§ 3$ ст. 79 удостоверение журналиста не является фактором, влияющим на статус сотрудника СМИ по международному гуманитарному праву. Иными словами, наличие или отсутствие такого удостоверения не может рассматриваться как основание для лишения журналиста международно-правовой защиты. В то же время такое удостоверение в случае его выдачи компетентным по смыслу данной статьи Дополнительного протокола I государственным органом может стать эффективным средством идентификации журналистов, работающих в зоне вооруженного конфликта. В этой связи озабоченность вызывает стремление ряда представителей СМИ действовать в обход устанавливаемых участниками конфликтов правил аккредитации журналистов и их передвижения в зоне боевых действий. Такая практика чревата ухудшением условий безопасности журналистской деятельности, т.к. она осложняет задачу участников конфликта по эффективной защите представителей СМИ.

Особого внимания заслуживает проблема злоупотребления журналистами своим статусом покровительствуемого лица по международному гуманитарному праву. По обстоятельствам общего принципа права (ст. 38 Статуса Международного суда), согласно которому обозначена недопустимость злоупотребления правом, представляется неприемлемой ситуация, когда представители СМИ в угоду узкопрофессиональным интересам злоупотребляют своим статусом и фактически выступают в поддержку одной из сторон конфликта, например, участвуя в пропагандистском обеспечении ее военных операций [11. c. $319-329]$, [20, c. 74-76], [21, c. 217].

По объективным показателям своего существа институт покровительствуемых лиц, как он себя предметно показывает в рамках международного гуманитарного права, носит целостный по форме и законченный по существу характер. Общий концептуальный посыл здесь состоит в представлении комплекса субъективных прав (по защите в рамках международного 
права) в ответ на востребование соблюдения норм международного гуманитарного права. Как и в любой иной отрасли права, факт несоблюдения предписываемых обязанностей вводит в действие юридическую ответственность соответствующих фигурантов. Параметры прав субъектов покровительствуемого состава сводятся к праву на гуманное отношение; на уважение личности, чести и достоинства; на защиту и помощь; на покровительство.

Характер устанавливаемых обязанностей для лиц покровительствуемого состава проявляет себя в обязанности не участвовать в военных действиях; соблюдать нормы международного гуманитарного права.

Ответственность фигурантов наступает по обстоятельствам законов юридической логики в силу несоблюдения соответствующих, обозначенных правом, обязанностей. Соответственно, ответственность идет по линии утраты права на покровительство (прекращается международно-правовая защита).

В миропорядке на основе верховенства права Rule of Law (Декларация тысячелетия 2000 г., Итоговый документ Всемирного саммита 2005 г.) общий позитив современного международного права предметно обозначает себя по линии создания целостной системы международной законности и правопорядка. Юридическая безопасность (совокупность субъективных прав и обязанностей) всего субъектного состава системы международных прав поддерживается в параметрах целостности всей системы международного права.
В параметрах миропорядка на основе верховенства права с его установочными принципами права поддержания международного мира, недопустимости угрозы силой или ее применения, уважения прав человека юридическая безопасность распространяется в формате всего субъектного состава международных правоотношений: государств, международных организаций, юридических и физических лиц. И далее, по обстоятельствам возникшего de facto вооруженного конфликта востребованность обеспечения юридической безопасности обозначает себя уже по линии конкретной ситуации по линии участников вооруженного конфликта. В случае, когда ситуация вооруженного конфликта по факту своей юридической логики составляет собой прямое нарушение принципа недопустимости угрозы силой или ее применения, разрешение всего спора (с учетом ситуации вооруженного конфликта) посредствам принципа мирного разрешения споров (Глава VI Устава ООН) через Международный суд как главный судебный органа $\mathrm{OOH}$ представляется юридически логическим и, соответственно, востребованным способом перевода всей возникшей de facto ситуации в формат общего режима современного международного права. В параметрах заявленной приверженности государств-членов мирового сообщества верховенству права режим добросовестного выполнения всеми государствами-членами мирового сообщества своих международных обязательств согласно Уставу ООН создает оптимально приемлемый формат развития мирового права и справедливости.

\section{Библиография:}

1. Иванов И.С. Верховенство права в международных отношениях//Международная жизнь. 2000. № 12. С. 62-67.

2. Каламкарян P.А. Господство права Rule of Law в международных отношениях. M., 2004. 
3. Каламкарян Р.А. Международный суд в миропорядке на основе господства права. М., 2012.

4. Dicey A.V. Introduction to the study of the low constitution. London,1960; Renouf A. Rule of Law in international affairs//Australian Foreign Affairs Record.1975. July. P.345-405.

5. Jackson S.W. The rule of low among nations// The rule of low. Dallas. 1961. P. 71-86.

6. Лукашева Е.А. /Права человека. М., 2001. С. 547.

7. Егоров С.А. Актуальные проблемы права вооруженных конфликтов: Учебное пособие. М., 2000. С. 25.

8. Военно-теоретический журнал «Военная мысль» № 4//Оружие нелетального действия на основе излучений: физические особенности и перспективы применения. М., 2013. С. 31.

9. Гассер Х.П. Международное гуманитарное право. М., 1995. С.34; Пикте Ж. Развитие и принципы международного гуманитарного права. М., 1993. С. 50.

10. Кальсховен Ф. Ограничения методов и средств ведения войны. М., 1999. С. 51.

11. Батырь В.А. Международное гуманитарное право. М., 2011. С. 319-329.

12. Фуркало В.В. Международно-правовая защита гражданского населения в условиях вооруженных конфликтов. Киев, 1986. С. 44.

13. Дополнительный протокол I к Женевским конвенциям от 12 августа 1949 г., касающийся защиты жертв международных вооруженных конфликтов. Ст. 58.

14. Женевская конвенция от 12 августа 1949 г./О защите гражданского населения во время войны, ст.30, $42,43$.

15. Арцибасов И.Н., Егоров С.А. Вооруженный конфликт: право, политика, дипломатия. М., 1989. С. 248.

16. Крилль Ф. Защита объектов в международном гуманитарном праве/ Сборник статей и документов. M., 1999. С. 108.

17. Сингер С. Дети и война/ Сборник статей. М., 1995, С. 44

18. Катажин Н. правовые аспекты защиты детей в вооруженных конфликтах//Московский журнал международного права. 2007. № 4. С. 217.

19. Levie H.S. Protection of War Victims, Protocol I to the 1949 Geneva Conventions. N.Y., 1979. Vol. IV. P. 135.

20. Пустогаров В.В. Проблемы международного гуманитарного права// Государство и право. 1997. № 9. C. 74-76.

21. Котляров И.И. Международное гуманитарное право. М., 2009. С. 74-76; Катажин Н. Правовые аспекты защиты детей в вооруженных конфликтах//Московский журнал международного права. 2007. № 4. C. 217.

22. Алешин В.В. Международное право вооруженных конфликтов. М., 2007. С. 200.

23. Альма Баччино-Астрада. Права и обязанности медицинского персонала в вооруженных конфликтах. M., 1995. C. 29.

24. Нахлик С.Е.. Краткий очерк международного гуманитарного права. М., С. 29.

25. Саврыга К.П. Правомерность целевых убийств в международном праве: международное гуманитарное право и права человека. // Право и политика. -2015. - 6. - С. 826 - 839. DOI: 10.7256/1811-9018.2015.6.15525.

26. Зверев П.Г. Проблемы взаимодействия международной защиты прав человека и международного гуманитарного права во время вооруженных конфликтов // Международное право. - 2015. - 4. - С. 1 - 22. DOI: 10.7256/2306-9899.2015.4.16552. URL: http://www.e-notabene.ru/wl/article_16552.html.

27. Саврыга К.П. Правомерность целевых убийств в международном праве: международное гуманитарное право и права человека. // Право и политика. -2015. - 6. - С. 826 - 839. DOI: 10.7256/1811-9018.2015.6.15525.

\section{References (transliterated):}

1. Ivanov I.S. Verkhovenstvo prava v mezhdunarodnykh otnosheniyakh//Mezhdunarodnaya zhizn'. 2000. № 12. S. 62-67.

2. Kalamkaryan R.A. Gospodstvo prava Rule of Law v mezhdunarodnykh otnosheniyakh. M., 2004.

3. Kalamkaryan R.A. Mezhdunarodnyi sud v miroporyadke na osnove gospodstva prava. M., 2012.

4. Dicey A.V. Introduction to the study of the low constitution. London,1960; Renouf A. Rule of Law in international affairs//Australian Foreign Affairs Record.1975. July. P.345-405. 
5. Jackson S.W. The rule of low among nations// The rule of low. Dallas. 1961. P. 71-86.

6. Lukasheva E.A. /Prava cheloveka. M., 2001. S. 547.

7. Egorov S.A. Aktual'nye problemy prava vooruzhennykh konfliktov: Uchebnoe posobie. M., 2000. S. 25.

8. Gasser Kh.P. Mezhdunarodnoe gumanitarnoe pravo. M., 1995. S.34; Pikte Zh. Razvitie i printsipy mezhdunarodnogo gumanitarnogo prava. M., 1993. S. 50.

9. Kal'skhoven F. Ogranicheniya metodov i sredstv vedeniya voiny. M., 1999. S. 51.

10. Batyr' V.A. Mezhdunarodnoe gumanitarnoe pravo. M., 2011. S. 319-329.

11. Furkalo V.V. Mezhdunarodno-pravovaya zashchita grazhdanskogo naseleniya v usloviyakh vooruzhennykh konfliktov. Kiev, 1986. S. 44.

12. Artsibasov I.N., Egorov S.A. Vooruzhennyi konflikt: pravo, politika, diplomatiya. M., 1989. S. 248.

13. Krill' F. Zashchita ob"'ektov v mezhdunarodnom gumanitarnom prave/ Sbornik statei i dokumentov. M., 1999. S. 108.

14. Singer S. Deti i voina/ Sbornik statei. M., 1995, S. 44

15. Katazhin N. pravovye aspekty zashchity detei v vooruzhennykh konfliktakh//Moskovskii zhurnal mezhdunarodnogo prava. 2007. № 4. S. 217.

16. Levie H.S. Protection of War Victims, Protocol I to the 1949 Geneva Conventions. N.Y., 1979. Vol. IV. P. 135.

17. Pustogarov V.V. Problemy mezhdunarodnogo gumanitarnogo prava// Gosudarstvo i pravo. 1997. № 9. S. 74-76.

18. Kotlyarov I.I. Mezhdunarodnoe gumanitarnoe pravo. M., 2009. S. 74-76; Katazhin N. Pravovye aspekty zashchity detei v vooruzhennykh konfliktakh//Moskovskii zhurnal mezhdunarodnogo prava. 2007. № 4. S. 217.

19. Aleshin V.V. Mezhdunarodnoe pravo vooruzhennykh konfliktov. M., 2007. S. 200.

20. Al'ma Bachchino-Astrada. Prava i obyazannosti meditsinskogo personala v vooruzhennykh konfliktakh. M., 1995. S. 29.

21. Nakhlik S.E.. Kratkii ocherk mezhdunarodnogo gumanitarnogo prava. M., S. 29.

22. Savryga K.P. Pravomernost' tselevykh ubiistv v mezhdunarodnom prave: mezhdunarodnoe gumanitarnoe pravo i prava cheloveka. // Pravo i politika. - 2015. - 6. - C. 826 - 839. DOI: 10.7256/1811-9018.2015.6.15525.

23. Zverev P.G. Problemy vzaimodeistviya mezhdunarodnoi zashchity prav cheloveka i mezhdunarodnogo gumanitarnogo prava vo vremya vooruzhennykh konfliktov // Mezhdunarodnoe pravo. - 2015. - 4. - C. 1 - 22. DOI: 10.7256/2306-9899.2015.4.16552. URL: http://www.e-notabene.ru/wl/article_16552.html.

24. Savryga K.P. Pravomernost' tselevykh ubiistv v mezhdunarodnom prave: mezhdunarodnoe gumanitarnoe pravo i prava cheloveka. // Pravo i politika. - 2015. - 6. - C. 826 - 839. DOI: 10.7256/1811-9018.2015.6.15525. 